\title{
Determination of activation energy and pre-exponential factor for individual compounds on release from kerogen by a laboratory heating experiment
}

\author{
Masahiro Oba, HaJime Mita and Akira Shimoyama* \\ Department of Chemistry, University of Tsukuba, Tsukuba 305-8571, Japan \\ (Received August 30, 2001; Accepted November 27, 2001)
}

\begin{abstract}
Kerogen recovered from Neogene Shinjo sediments was heated from room temperature to $800^{\circ} \mathrm{C}$ using a thermogravimetric analyzer (TG). Organic compounds released from kerogen during heating were trapped and analyzed by a gas chromatograph (GC)-mass spectrometer (MS). Among these compounds, benzene, hexane, toluene, phenol, heptane, and indene were selected to determine temperatures at which maximum release of these compounds occurred based on TG-MS peak profiles. This analysis was carried out using programmed heating rates $(\mathrm{Hr})$ of $5,10,20,30$, and $60^{\circ} \mathrm{C} \mathrm{min}^{-1}$ and five temperatures at peak tops $\left(T_{\max }\right.$ in absolute temperature) were determined for each compound. The plot of $1 / T_{\max } \mathrm{vs} . \ln \left(H \mathrm{r} /\left(T_{\max }\right)^{2}\right)$ for each compound showed a good straight line with a high correlation coefficiency. Accordingly, a mean activation energy $\left(E_{0}\right)$ and pre-exponential factor $(A)$ at $E_{0}$ for each compound on the release from kerogen were calculated, using the equation of the approximate method (or Gaussian $E$-distribution method) by Braun and Burnham (1987),

$$
\ln \left(H \mathrm{r} /\left(T_{\max }\right)^{2}\right)=-E_{0} / R T_{\max }+\ln \left(A R / E_{0}\right)
$$

where $R$ is the ideal gas constant. The activation energies and pre-exponential factors of these compounds were in a range of 43.1 to $60.9 \mathrm{kcal} / \mathrm{mol}$ and of $3.56 \times 10^{10}$ to $1.21 \times 10^{16} \mathrm{~s}^{-1}$, respectively. The averages of the activation energies and pre-exponential factors obtained from the five kerogens had decomposition rates in order of indene > benzene, toluene > phenol > hexane, heptane, which indicated that hexane and heptane were more strongly bound to kerogen than the three aromatic hydrocarbons.
\end{abstract}

\section{INTRODUCTION}

It has been widely accepted that petroleum hydrocarbons are generated mainly by thermal decomposition of kerogen in sediments. Some studies described the hydrocarbon generation from kerogen by kinetic models using data obtained by heating experiments. The Rock-Eval pyrolysis method has been used for that purpose (Ungerer et al., 1986; Tissot et al., 1987; Burnham et al., 1987; Ungerer and Pelet, 1987; Sweeney et al., 1990; Jarvie, 1991). This pyrolysis method gives three peaks by detection, which correspond to those for hydrocarbons in free form, hydrocarbons released from kerogen, and $\mathrm{CO}_{2}$ from kerogen. Since the first two peaks include mixtures of compounds, their activation energies and pre-exponential (or frequency) factors are only average values of the mixtures. Each compound on the release from kerogen has its own values of activation energy and pre-exponential factor, and therefore it is difficult to determine these values for each compound by this method.

For identification of compounds released from

*Corresponding author (e-mail: ashimoya@staff.chem.tsukuba.ac.jp) 
kerogen and for determination of their release temperatures, a thermogravimetric analyzer (TG) was connected to a gas chromatograph-mass spectrometer (GC/MS) and to a mass spectrometer (MS), respectively (Komiya et al., 1990; Oba et al., 2000). This system enables determination of the activation energy and pre-exponential factor of an individual compound on the release from kerogen by changing the rate of experimental heating on a given sample. Therefore, we examined kerogen in Neogene Shinjo sediments by this approach to obtain the activation energy and preexponential factor for an individual compound. Here we report the results of thermal investigation of kerogen and present the values obtained by this technique.

\section{SAMPLES}

Kerogen samples were prepared from Neogene sediments collected at outcrops along the Oashizawa route in the Shinjo basin in Yamagata Prefecture, northeastern Japan, in 1980, as common samples for the study of organic and inorganic constituents and their diagenesis (Taguchi et al., 1983). The sediment samples are mainly marine shales and mudstones from Middle Miocene to Pliocene, and were numbered discontinuously from No. 90105 (bottom) to No. 83110 (top) of the $1600 \mathrm{~m}$ thick sedimentary sequence. Some results of the joint study were summarized by Taguchi et al. (1986).

The method for preparation of kerogen was reported in the study of stable carbon isotopic ratios of kerogen (Shimoyama and Matsubaya, 1985). We used portions of 5 previously prepared kerogen samples Nos. 83109, 83105, 83101, 90101, and 90104 in this study. Investigation of organic compounds released from these kerogen samples by heating experiments using TG-GC/MS and TG-MS analyses was reported by Oba et al. (2000). The study identified a total of 249 compounds whose major organic compounds were aliphatic and aromatic hydrocarbons generally found as major constituents of petroleum.

\section{EXPERIMENTS}

The instrument configuration was illustrated by Komiya et al. (1990). In TG-GC/MS analysis, a kerogen sample was heated under a helium flow from room temperature to $800^{\circ} \mathrm{C}$ at a rate of $60^{\circ} \mathrm{C}$ $\mathrm{min}^{-1}$ in TG (Shimadzu TGA-50). During the heating experiment, the kerogen weight was continuously monitored by TG with temperature. Compounds released from kerogen by heating were transported by helium flow to a cold trap in liquid nitrogen. The trap was made of an uncoated fused silica capillary tube $(1 \mathrm{~m} \times 0.25 \mathrm{~mm}$ i.d. $)$. After the heating, the trap was placed in the GC (Hewlett Packard 6890) oven maintained at $30^{\circ} \mathrm{C}$. The trapped compounds were vaporized in the trap by the temperature increase of the GC oven and introduced into a GC capillary column (DB-5HT, $30 \mathrm{~m} \times 0.25 \mathrm{~mm}$ i.d., J\&W Scientific) and MS (Hewlett Packard 5973 with Mass Selective Detector) by helium carrier gas. The GC oven temperature was programmed at an increasing rate of $1{ }^{\circ} \mathrm{C} \mathrm{min}{ }^{-1}$ from 30 to $40^{\circ} \mathrm{C}, 2^{\circ} \mathrm{C} \mathrm{min}^{-1}$ from 40 to $60^{\circ} \mathrm{C}, 3^{\circ} \mathrm{C} \mathrm{min}{ }^{-1}$ from 60 to $100^{\circ} \mathrm{C}, 4^{\circ} \mathrm{C} \mathrm{min}^{-1}$ from 100 to $200^{\circ} \mathrm{C}$, and $5^{\circ} \mathrm{C} \mathrm{min}^{-1}$ from 200 to $350^{\circ} \mathrm{C}$. MS was scanned every $0.31 \mathrm{sec}$ over $\mathrm{m} / \mathrm{z}, 40-500$ in the electron impact mode at $70 \mathrm{eV}$.

In the TG-MS analysis, a kerogen sample was heated in TG under a helium flow from room temperature to $800^{\circ} \mathrm{C}$ at increasing rates of $5,10,20$, 30 , and $60^{\circ} \mathrm{C} \mathrm{min}^{-1}$. The heating rates were controlled by a thermocouple just above the kerogen sample. Released compounds were introduced directly and without a significant delay to MS by helium flow. MS was scanned every 0.31 sec over $\mathrm{m} / \mathrm{z}, 40-550$ in the electron impact ionization mode at $70 \mathrm{eV}$.

\section{RESUlTS AND DISCUSSION}

\section{Identification by TG-GC/MS and TG-MS}

Figure 1 shows mass fragmentograms of $\mathrm{m} / \mathrm{z}$ $78,86,92,94,100$, and 116 for the compounds released from the kerogen sample No. 83105 by the TG-GC/MS analysis. The other kerogen sam- 
a) $m / z 78$ Benzene

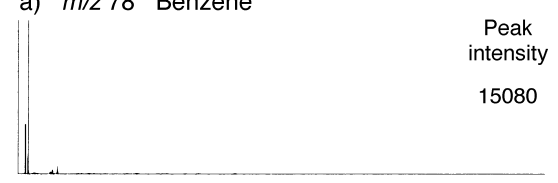

b) $m / z 86$ Hexane

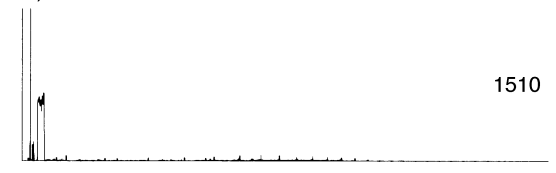

c) $m / z 92$ Toluene

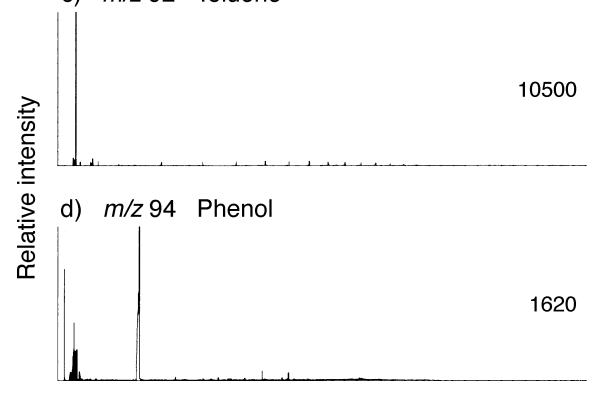

e) $m / z 100$ Heptane
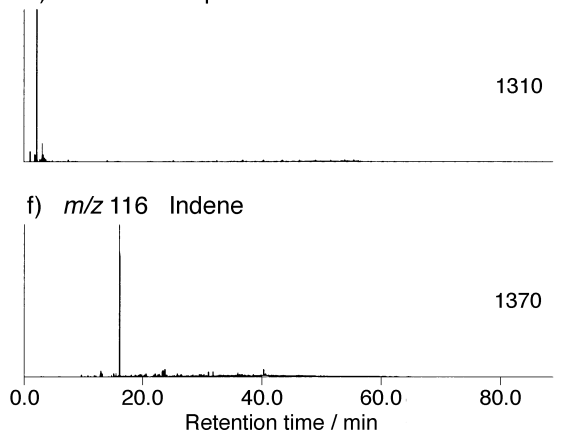

Fig. 1. Mass fragmentograms ( $\mathrm{m} / \mathrm{z}, 78,86,92,94,100$, and 116) of compounds released from kerogen sample No. 83105 by TG-GC/MS analysis.

ples showed similar mass fragmentograms of those $\mathrm{m} / \mathrm{z}$ to those of the sample No. 83105 .

The mass fragmentogram of $m / z 78$ by the TGGC/MS analysis (Fig. 1(a)) showed a large peak at about $1.9 \mathrm{~min}$ and a small one at about $1.4 \mathrm{~min}$. These two peaks were identified as benzene and carbon disulfide $\left(\mathrm{C}^{32} \mathrm{~S}^{34} \mathrm{~S}\right)$, respectively, based on their mass spectra. The compound release profile of $\mathrm{m} / \mathrm{z} 78$ by the TG-MS analysis (Fig. 2(a)) showed a large and a small peak. Because the temperature of the small peak coincided with that of

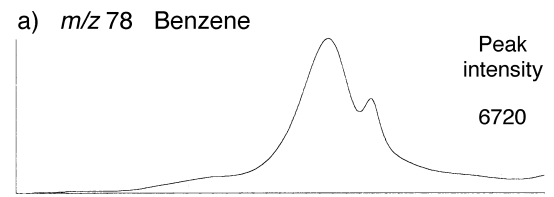

b) $m / z 86$ Hexane

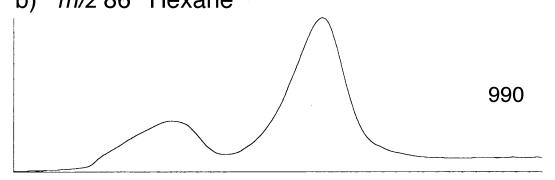

c) $m / z 92$ Toluene

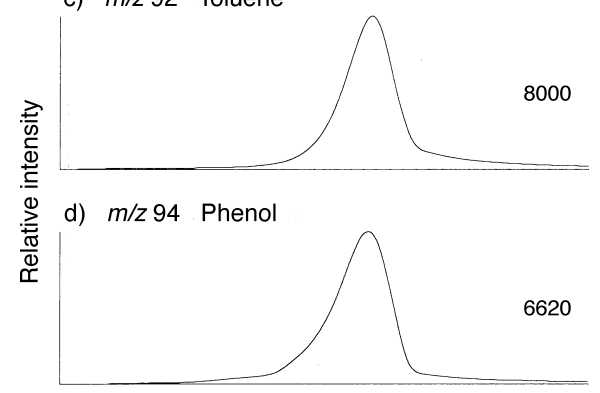

e) $m / z 100$ Heptane
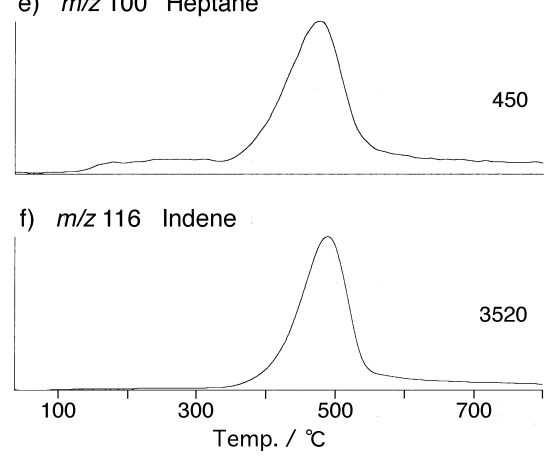

Fig. 2. Compound release profiles $(\mathrm{m} / \mathrm{z}, 78,86,92,94$, 100, and 116) from kerogen sample No. 83105 by TGMS analysis (temperature increasing rate at $20^{\circ} \mathrm{C}$ $\mathrm{min}^{-1}$ ).

the thermal decomposition of pyrite as revealed by the TG analysis, this peak was carbon disulfide which was probably formed by the reaction of the carbon residue in kerogen and sulfur produced from the thermal decomposition of pyrite in kerogen. Therefore, the large peak on the profiles was assigned to benzene released from kerogen.

The mass fragmentogram of $m / z 86$ (Fig. 1(b)) showed a large peak at about $1.5 \mathrm{~min}$ in retention time and a broad one from about 2.8 to $3.9 \mathrm{~min}$. 

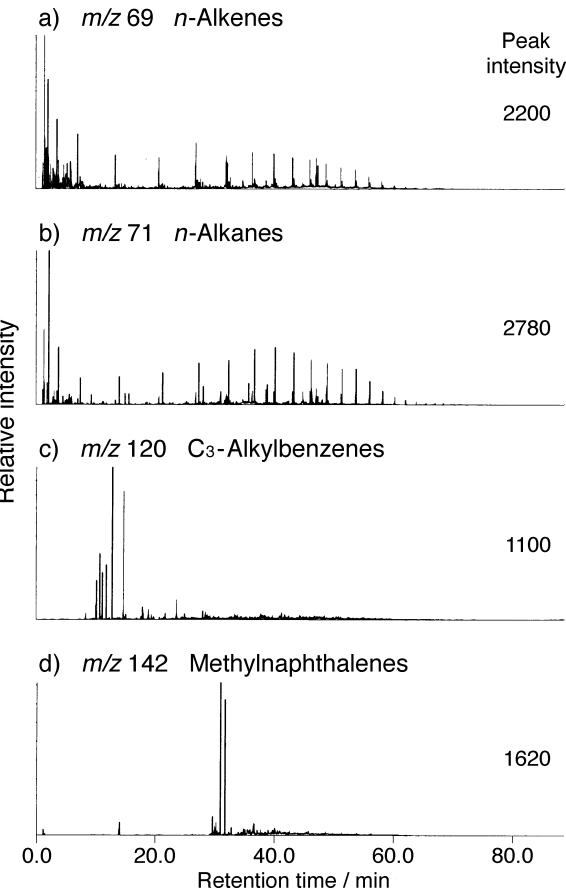

Fig. 3. Mass fragmentograms $(\mathrm{m} / \mathrm{z}, 69,71,120$, and 142) of organic compounds released from kerogen sample No. 83105 by TG-GC/MS analysis.

According to their mass spectra, these two peaks were identified as hexane and tetrafluorosilane $\left(\mathrm{SiF}_{4}\right)$, respectively. The $m / z 86$ corresponds to the molecular ion of hexane and a fragment ion $\left(\mathrm{SiF}_{3}{ }^{+}\right)$ of tetrafluorosilane. The tetrafluorosilane was probably formed during the preparation of kerogen samples. The compound release profile of $\mathrm{m} / \mathrm{z} 86$ (Fig. 2(b)) showed two peaks. The peak at about $250^{\circ} \mathrm{C}$ was identified as tetrafluorosilane according to the mass spectrum. Therefore, the peak at about $500^{\circ} \mathrm{C}$ was hexane released from kerogen.

The mass fragmentograms of $\mathrm{m} / z$ 92, 100, and 116 (Figs. 1(c), (e), and (f)) showed only one peak on the mass fragmentograms. These peaks were assigned to toluene, heptane and indene, respectively, based on their mass spectra. The mass fragmentogram of $\mathrm{m} / \mathrm{z}, 94$ (Fig. 1(d)) showed one large peak at about $15 \mathrm{~min}$ in retention time and some peaks at about $5 \mathrm{~min}$. The large peak was phenol based on retention time, mass spectrum of a standard compound, and its much larger size.
Therefore, it was concluded that the peaks on the compound release profiles of $m / z$ 92, 94, 100, and 114 (Figs. 2(c)-(f)) were of toluene, phenol, heptane, and indene, respectively.

On the other mass fragmentograms, more than two peaks were detected. For instance, the mass fragmentograms of $m / z 69$ (Fig. 3(a)) and 71 (Fig. 3(b)) showed peak distribution patterns of homologous compounds. The ion at $\mathrm{m} / \mathrm{z} 69$ corresponds to $\mathrm{C}_{5} \mathrm{H}_{9}{ }^{+}$and $\mathrm{m} / z, 71$ to $\mathrm{C}_{5} \mathrm{H}_{11}{ }^{+}$, which are common mass fragments of $n$-alkenes and $n$-alkanes, respectively. Accordingly, a series of $n$-alkenes (ranging from $\mathrm{C}_{6}$ to $\mathrm{C}_{25}$ ) and a series of $n$-alkanes (ranging from $\mathrm{C}_{6}$ to $\mathrm{C}_{28}$ ) were identified. The mass fragmentograms of $\mathrm{m} / \mathrm{z} 120$ (Fig. 3(c)) and 142 (Fig. 3(d)) showed peaks of 7 isomers of $\mathrm{C}_{3}$ alkylbenzenes (molecular ion 120) and 2 of methylnaphthalenes (molecular ion 142), respectively. Although the compound release profiles of these four mass fragmentograms showed peaks at about $500^{\circ} \mathrm{C}$, each peak consisted of mixtures of above compounds. Therefore, those mass fragmentograms and their compound release profiles were not used for the present purpose.

\section{Determination of $T_{\max }$}

Figure 4(a) shows the release profiles of toluene $(m / z$ 92) from the kerogen sample No. 83105 and Fig. 4(b) of heptane $(\mathrm{m} / \mathrm{z}$ 100) from No. 90101 heated at temperature increase rates of $5,10,20$, 30 , and $60^{\circ} \mathrm{C} \mathrm{min}{ }^{-1}$. These heating rates were selected for practical reasons. Considerably lower rates (e.g., $0.1^{\circ} \mathrm{C} \mathrm{min}{ }^{-1}$ ) would require about five days for the completion of a heating experiment, whereas higher heating rates are known to cause significant differences between the real temperature of the sample and the programmed rate. This problem has been discussed in detail by Burnham et al. (1987).

In order to estimate an activation energy and pre-exponential factor, $T_{\max }$ (temperature at peak top) was determined. For the estimation of the time lag between compound release from the kerogen sample in TG and detection by MS, the time at the peak top due to the decomposition of pyrite in the kerogen sample on the differential TG curve 


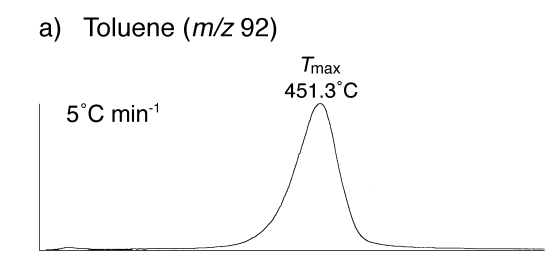

b) Heptane $(m / z 100)$
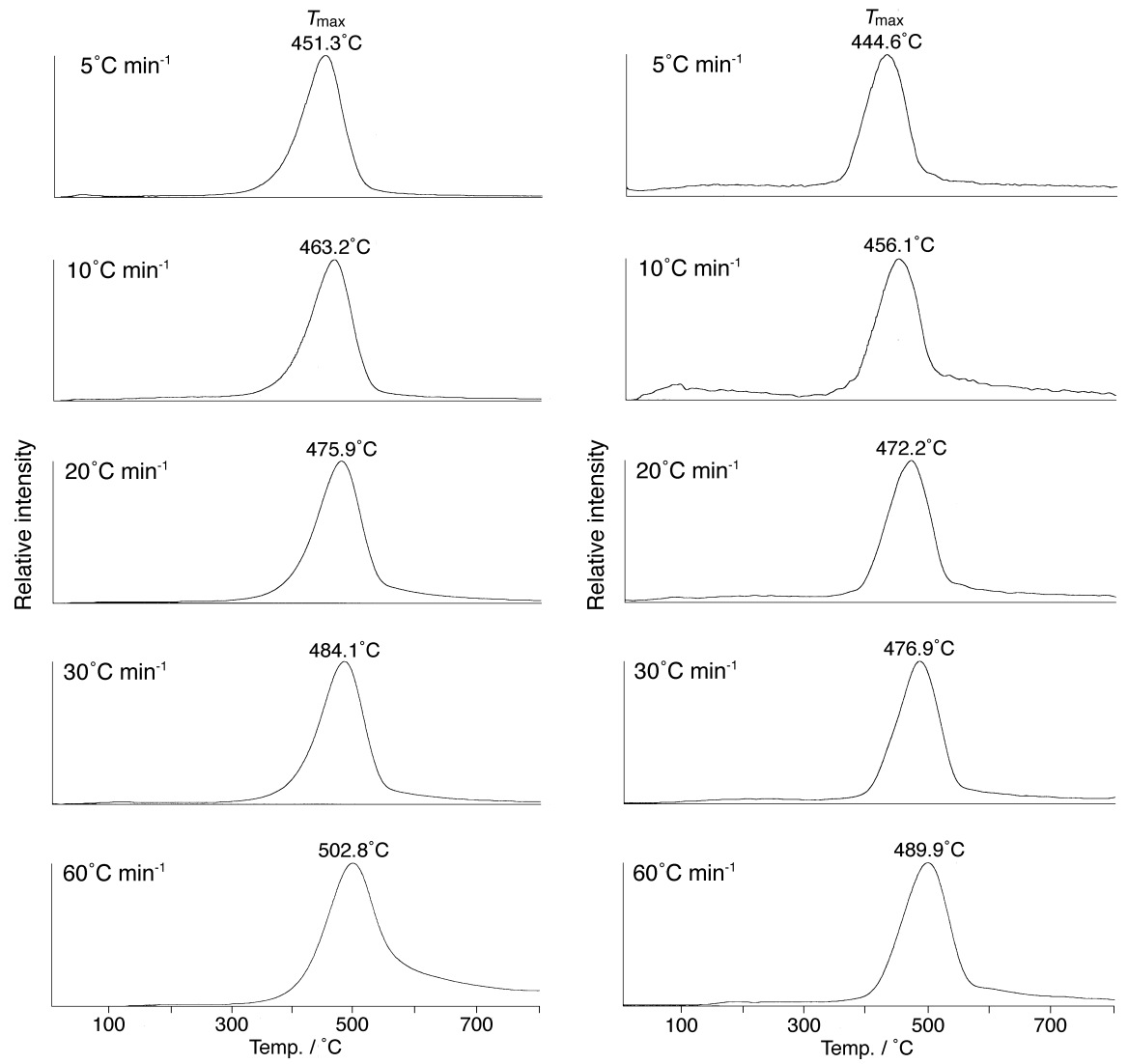

Fig. 4. Compound release profiles of toluene from kerogen sample No. 83105 (a) and heptane from kerogen sample No. 90101 (b) by TG-MS analysis.

and that of peak top on the compound release profile of $\mathrm{m} / \mathrm{z} 64$ for the molecular ion of $\mathrm{SO}_{2}$ were compared. Similarly the time lag was determined for each heating rate. Thus, $T_{\max }$ was determined by correcting the observed time at peak top using the time-temperature graph recorded by TG. Table 1 shows $T_{\max }$ of benzene, hexane, toluene, phenol, heptane, and indene at five heating rates. These $T_{\max }$ values shifted toward higher temperatures with increasing heating rates, and fell in a range between 424.6 and $459.9^{\circ} \mathrm{C}$ at $5^{\circ} \mathrm{C} \mathrm{min}^{-1}$, and so on as shown in Table 1. It is important to note that a slight change in $T_{\max }$ can significantly change the activation energy and pre-exponential factor. Therefore, considerable care was made to determine the correct $T_{\max }$.
Activation energy and pre-exponential factor

Assuming a first order reaction for the compound on the release from a kerogen sample, the activation energy and pre-exponential factor were determined from $T_{\max }$ with different heating rates using the equation of the approximate method (or Gaussian E-distribution method) by Braun and Burnham (1987):

$$
\ln \left(H \mathrm{r} /\left(T_{\max }\right)^{2}\right)=-E_{0} / R T_{\max }+\ln \left(A R / E_{0}\right)
$$

where $H \mathrm{r}$ is the heating rate $\left(\mathrm{K} \mathrm{min}^{-1}\right), E_{0}$ the mean activation energy of Gaussian distribution of activation energies, $A$ the pre-exponential factor at $E_{0}, R$ the ideal gas constant, and $T_{\max }$ in K. Figure 5 shows the plots of $1 / T_{\max }$ vs. $\ln \left(H \mathrm{r} /\left(T_{\max }\right)^{2}\right)$ for 
Table 1. $T_{\max }$ of benzene, hexane, toluene, phenol, heptane, and indene on release from kerogen samples in Shinjo sediments

\begin{tabular}{|c|c|c|c|c|c|c|c|}
\hline \multirow[t]{2}{*}{ Kerogen } & \multirow[t]{2}{*}{$\mathrm{m} / \mathrm{z}$} & \multirow[t]{2}{*}{ Compounds } & \multicolumn{5}{|c|}{$T_{\max } /{ }^{\circ} \mathrm{C}$} \\
\hline & & & $5^{\circ} \mathrm{C} \min ^{-1}$ & $10^{\circ} \mathrm{C} \min ^{-1}$ & $20^{\circ} \mathrm{C} \min ^{-1}$ & $30^{\circ} \mathrm{C} \min ^{-1}$ & $60^{\circ} \mathrm{C} \mathrm{min}^{-1}$ \\
\hline \multirow[t]{6}{*}{83109} & 78 & Benzene & 439.6 & 453.7 & 470.2 & 477.3 & 493.4 \\
\hline & 86 & Hexane & 435.6 & 450.0 & 460.9 & 468.1 & 478.5 \\
\hline & 92 & Toluene & 440.5 & 455.4 & 473.4 & 480.3 & 494.4 \\
\hline & 94 & Phenol & 428.2 & 441.0 & 454.4 & 461.2 & 473.8 \\
\hline & 100 & Heptane & 424.6 & 434.3 & 449.4 & 457.6 & 469.7 \\
\hline & 116 & Indene & 442.1 & 453.9 & 473.8 & 481.3 & 497.4 \\
\hline \multirow[t]{6}{*}{83105} & 78 & Benzene & 451.2 & 462.4 & 475.7 & 482.5 & 504.4 \\
\hline & 86 & Hexane & 448.0 & 458.1 & 470.1 & 478.2 & 494.2 \\
\hline & 92 & Toluene & 451.3 & 463.2 & 475.9 & 484.1 & 502.8 \\
\hline & 94 & Phenol & 454.8 & 464.0 & 476.2 & 483.7 & 502.8 \\
\hline & 100 & Heptane & 443.8 & 455.2 & 465.0 & 473.0 & 488.6 \\
\hline & 116 & Indene & 451.2 & 464.8 & 477.9 & 485.2 & 510.7 \\
\hline \multirow[t]{6}{*}{83101} & 78 & Benzene & 454.0 & 466.7 & 481.6 & 488.8 & 511.8 \\
\hline & 86 & Hexane & 452.0 & 464.5 & 477.7 & 485.0 & 502.5 \\
\hline & 92 & Toluene & 454.0 & 467.8 & 481.8 & 489.1 & 510.9 \\
\hline & 94 & Phenol & 451.6 & 464.6 & 477.4 & 484.5 & 504.9 \\
\hline & 100 & Heptane & 447.1 & 460.4 & 472.4 & 481.5 & 495.9 \\
\hline & 116 & Indene & 452.7 & 469.1 & 482.1 & 489.1 & 515.7 \\
\hline \multirow[t]{6}{*}{90101} & 78 & Benzene & 453.3 & 467.2 & 482.0 & 487.6 & 501.9 \\
\hline & 86 & Hexane & 450.1 & 463.7 & 477.9 & 481.9 & 494.8 \\
\hline & 92 & Toluene & 454.4 & 467.7 & 481.1 & 487.5 & 499.8 \\
\hline & 94 & Phenol & 449.4 & 462.1 & 475.5 & 480.5 & 491.9 \\
\hline & 100 & Heptane & 444.6 & 456.1 & 472.2 & 476.9 & 489.9 \\
\hline & 116 & Indene & 451.4 & 466.7 & 480.5 & 484.6 & 499.8 \\
\hline \multirow[t]{6}{*}{90104} & 78 & Benzene & 458.1 & 470.0 & 479.4 & 493.6 & 513.7 \\
\hline & 86 & Hexane & 456.3 & 465.7 & 476.3 & 490.6 & 506.4 \\
\hline & 92 & Toluene & 459.9 & 470.8 & 488.5 & 494.6 & 513.7 \\
\hline & 94 & Phenol & 453.6 & 464.0 & 478.7 & 486.2 & 505.7 \\
\hline & 100 & Heptane & 453.3 & 464.3 & 475.8 & 486.2 & 501.7 \\
\hline & 116 & Indene & 459.3 & 470.4 & 482.3 & 496.4 & 516.9 \\
\hline
\end{tabular}

benzene, hexane, toluene, phenol, heptane, and indene. All plots showed reasonably straight lines with high correlation coefficiencies ( $r$ ) from 0.999 (heptane from the kerogen sample No. 83101) to 0.977 (phenol from No. 83105). The activation energies and pre-exponential factors for these compounds on the release from five kerogen samples obtained by these means are listed in Table 2 . The activation energy and pre-exponential factor of phenol from No. 90101 were $60.9 \mathrm{kcal} / \mathrm{mol}$ and $1.21 \times 10^{16} \mathrm{~s}^{-1}$, respectively, which was the largest among the values of all released com- pounds of all kerogen samples. Conversely, 43.1 $\mathrm{kcal} / \mathrm{mol}$ and $3.56 \times 10^{10} \mathrm{~s}^{-1}$ for indene from No. 83101 was the lowest. The values of kinetic parameters for each compound did not reflect the difference in kerogens of different burial depth, except that the values for compounds from the kerogen sample No. 90101 were somewhat higher than those for the other kerogen samples.

The rate constants of each compound at $120^{\circ} \mathrm{C}$ were calculated using the Arrhenius expression (Table 2). The joint study on the organic and inorganic diagenesis in the Shinjo sediments con- 
a) Benzene

$\ln \left(\mathrm{Hr} /(\mathrm{Tmax})^{2}\right)=-2.50 \times 10^{4}(1 / \mathrm{Tmax})+23.1$

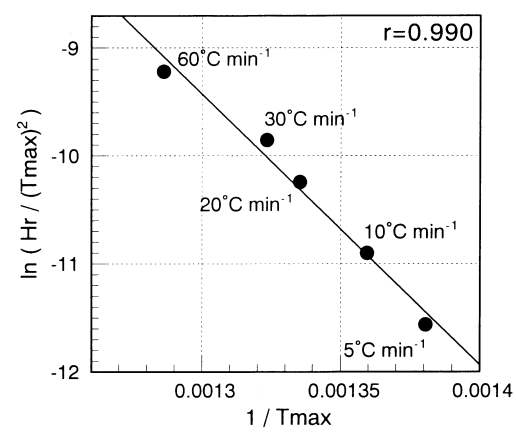

c) Toluene

$\ln \left(\mathrm{Hr} /(\mathrm{T} \max )^{2}\right)=-2.59 \times 10^{4}(1 / \mathrm{Tmax})+24.2$

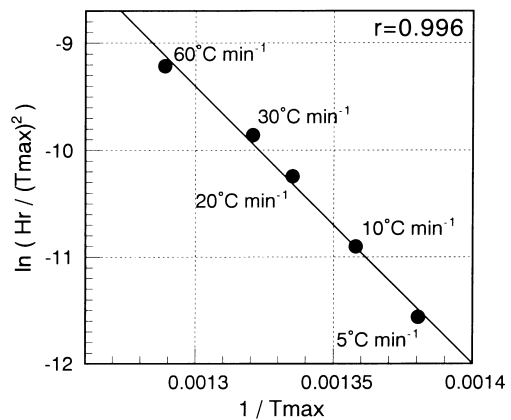

e) Heptane

In $\left(\mathrm{Hr} /(\mathrm{Tmax})^{2}\right)=-2.92 \times 10^{4}(1 / \mathrm{Tmax})+29.3$

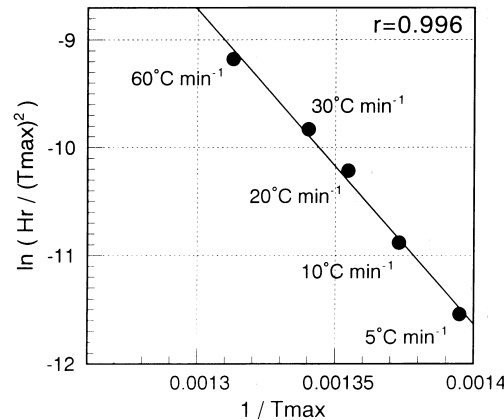

b) Hexane

In $\left(\mathrm{Hr} /(\mathrm{Tmax})^{2}\right)=-2.82 \times 10^{4}(1 / \mathrm{Tmax})+27.7$

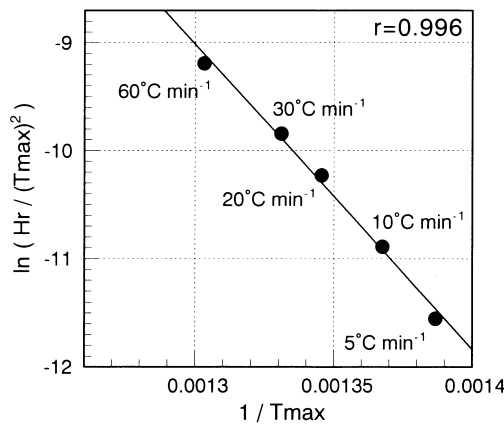

d) Phenol

$\ln \left(\mathrm{Hr} /(\mathrm{T} \max )^{2}\right)=-2.46 \times 10^{4}(1 / \mathrm{Tmax})+22.7$

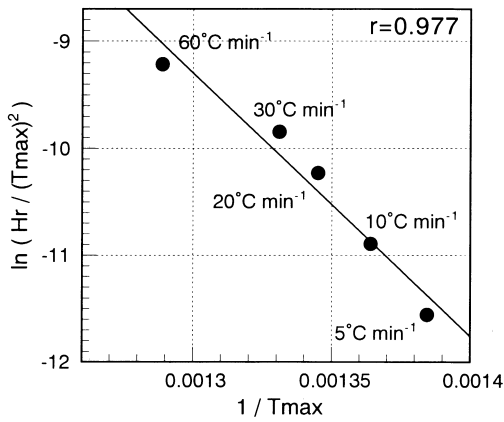

f) Indene

In $\left(\mathrm{Hr} /(\mathrm{Tmax})^{2}\right)=-2.26 \times 10^{4}(1 / \mathrm{Tmax})+19.8$

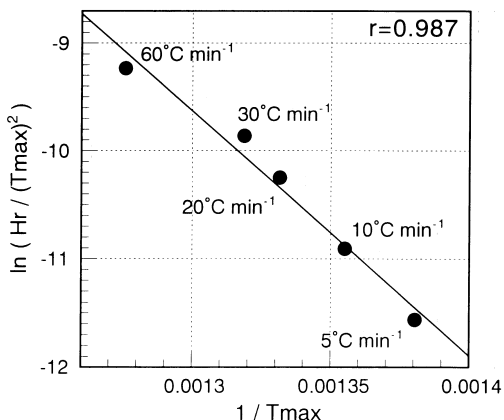

Fig. 5. $1 / T_{\max }-\ln \left(H r /\left(T_{\max }\right)^{2}\right)$ plots of benzene, hexane, toluene, phenol, heptane, and indene on the release from kerogen sample No. 83105.

cluded that petroleum generation took place mainly in the upper part of the Kusanagi Formation with the onset of the intense generation at $120^{\circ} \mathrm{C}$ (Taguchi et al., 1986). The fastest and slowest among those values in Table 2 were $3.89 \times$ $10^{-14} \mathrm{~s}^{-1}$ for indene from No. 83101 and $1.68 \times$
$10^{-18} \mathrm{~s}^{-1}$ for phenol from No. 90101 , respectively. The average values of the rate constants of each compound from five kerogen samples were in order of indene > benzene, toluene > phenol > hexane, heptane, whereas the average activation energies were inverse in order (Table 2). In this 
Table 2. Activation energies, pre-exponential factors and rate constants at $120^{\circ} \mathrm{C}$ of benzene, hexane, toluene, phenol, heptane, and indene on release from kerogen samples in Shinjo sediments

\begin{tabular}{|c|c|c|c|c|c|}
\hline$m / z$ & Compounds & Kerogen & $\begin{array}{l}\text { Activation energies } \\
\qquad(\mathrm{kcal} / \mathrm{mol})\end{array}$ & $\begin{array}{l}\text { Pre-exponential factors } \\
\qquad\left(\mathrm{s}^{-1}\right)\end{array}$ & $\begin{array}{l}\text { Rate constants at } 120^{\circ} \mathrm{C} \\
\qquad\left(\mathrm{s}^{-1}\right)\end{array}$ \\
\hline \multirow[t]{6}{*}{78} & \multirow[t]{6}{*}{ Benzene } & 83109 & 47.0 & $1.03 \times 10^{12}$ & $7.65 \times 10^{-15}$ \\
\hline & & 83105 & 49.7 & $4.37 \times 10^{12}$ & $1.02 \times 10^{-15}$ \\
\hline & & 83101 & 46.3 & $3.24 \times 10^{11}$ & $5.90 \times 10^{-15}$ \\
\hline & & 90101 & 54.3 & $9.35 \times 10^{13}$ & $6.07 \times 10^{-17}$ \\
\hline & & 90104 & 47.5 & $6.62 \times 10^{11}$ & $2.59 \times 10^{-15}$ \\
\hline & & average & 49.0 & $2.46 \times 10^{12}$ & $1.41 \times 10^{-15}$ \\
\hline \multirow[t]{6}{*}{86} & \multirow[t]{6}{*}{ Hexane } & 83109 & 58.5 & $4.76 \times 10^{15}$ & $1.43 \times 10^{-17}$ \\
\hline & & 83105 & 56.1 & $4.80 \times 10^{14}$ & $3.11 \times 10^{-17}$ \\
\hline & & 83101 & 52.6 & $3.12 \times 10^{13}$ & $1.79 \times 10^{-16}$ \\
\hline & & 90101 & 58.3 & $1.88 \times 10^{15}$ & $7.29 \times 10^{-18}$ \\
\hline & & 90104 & 51.0 & $8.87 \times 10^{12}$ & $3.94 \times 10^{-16}$ \\
\hline & & average & 55.3 & $2.60 \times 10^{14}$ & $4.69 \times 10^{-17}$ \\
\hline \multirow[t]{6}{*}{92} & \multirow[t]{6}{*}{ Toluene } & 83109 & 46.4 & $6.01 \times 10^{11}$ & $9.62 \times 10^{-15}$ \\
\hline & & 83105 & 51.4 & $1.41 \times 10^{13}$ & $3.75 \times 10^{-16}$ \\
\hline & & 83101 & 47.3 & $6.65 \times 10^{11}$ & $3.36 \times 10^{-15}$ \\
\hline & & 90101 & 58.0 & $1.20 \times 10^{15}$ & $6.83 \times 10^{-18}$ \\
\hline & & 90104 & 49.4 & $2.19 \times 10^{12}$ & $7.53 \times 10^{-16}$ \\
\hline & & average & 50.5 & $6.83 \times 10^{12}$ & $5.75 \times 10^{-16}$ \\
\hline \multirow[t]{6}{*}{94} & \multirow[t]{6}{*}{ Phenol } & 83109 & 53.6 & $2.29 \times 10^{14}$ & $3.64 \times 10^{-16}$ \\
\hline & & 83105 & 48.8 & $2.83 \times 10^{12}$ & $2.10 \times 10^{-15}$ \\
\hline & & 83101 & 50.2 & $5.73 \times 10^{12}$ & $7.08 \times 10^{-16}$ \\
\hline & & 90101 & 60.9 & $1.21 \times 10^{16}$ & $1.68 \times 10^{-18}$ \\
\hline & & 90104 & 50.4 & $6.60 \times 10^{12}$ & $6.31 \times 10^{-16}$ \\
\hline & & average & 52.8 & $4.95 \times 10^{13}$ & $2.19 \times 10^{-16}$ \\
\hline \multirow[t]{6}{*}{100} & \multirow[t]{6}{*}{ Heptane } & 83109 & 52.0 & $9.19 \times 10^{13}$ & $1.13 \times 10^{-15}$ \\
\hline & & 83105 & 58.0 & $2.47 \times 10^{15}$ & $1.41 \times 10^{-17}$ \\
\hline & & 83101 & 53.3 & $6.67 \times 10^{13}$ & $1.56 \times 10^{-16}$ \\
\hline & & 90101 & 55.7 & $4.13 \times 10^{14}$ & $4.47 \times 10^{-17}$ \\
\hline & & 90104 & 54.0 & $8.51 \times 10^{13}$ & $8.11 \times 10^{-17}$ \\
\hline & & average & 54.6 & $2.21 \times 10^{14}$ & $9.77 \times 10^{-17}$ \\
\hline \multirow[t]{6}{*}{116} & \multirow[t]{6}{*}{ Indene } & 83109 & 44.8 & $1.94 \times 10^{11}$ & $2.41 \times 10^{-14}$ \\
\hline & & 83105 & 44.9 & $1.46 \times 10^{11}$ & $1.59 \times 10^{-14}$ \\
\hline & & 83101 & 43.1 & $3.56 \times 10^{10}$ & $3.89 \times 10^{-14}$ \\
\hline & & 90101 & 55.0 & $1.64 \times 10^{14}$ & $4.35 \times 10^{-17}$ \\
\hline & & 90104 & 45.6 & $1.71 \times 10^{11}$ & $7.62 \times 10^{-15}$ \\
\hline & & average & 46.7 & $4.90 \times 10^{11}$ & $5.34 \times 10^{-15}$ \\
\hline
\end{tabular}


study, it is considered that the activation energy is the amount of energy required to break bonds. Therefore, it is hypothesized that hexane and heptane of aliphatic hydrocarbons are more strongly bound to kerogen than benzene, toluene, and indene of aromatic hydrocarbons based on their higher activation energies and slower decomposition rates.

Determination of activation energies and preexponential factors by the Rock-Eval pyrolysis has been performed on numerous samples. A narrow range of activation energies between $49 \mathrm{kcal} / \mathrm{mol}$ (Zumberge et al., 1988) and $56 \mathrm{kcal} / \mathrm{mol}$ (Ungerer and Pelet, 1987; Jarvie, 1991; Tegelaar and Noble, 1994) was found for organic compounds from the Type I kerogen. Tissot et al. (1987) reported $56 \mathrm{kcal} / \mathrm{mol}$ and the pre-exponential factors in a range of $10^{14} \mathrm{~s}^{-1}$ to $10^{18} \mathrm{~s}^{-1}$ for the Type I kerogen. The ranges were somewhat wider for marine kerogen (Type II) with activation energies and pre-exponential factors, $46 \mathrm{kcal} / \mathrm{mol}$ and $1.1 \times 10^{12} \mathrm{~s}^{-1}$ (Novelli et al., 1987), $53 \mathrm{kcal} / \mathrm{mol}$ and $9.7 \times 10^{13} \mathrm{~s}^{-1}$ (Jarvie, 1991), and $56 \mathrm{kcal} / \mathrm{mol}$ and $5.2 \times 10^{14} \mathrm{~s}^{-1}$ (Espitalié et al., 1988), respectively. The high sulfur kerogens in carbonate and sulfur-rich source rocks were reported to have lower activation energies than marine shales (Tissot et al., 1987; Tegelaar and Noble, 1994). Furthermore, the high oxygen and sulfur kerogens have lower activation energies than the high sulfur only kerogens (Jarvie and Lundell, 2001). Activation energies and pre-exponential factors for the Type III kerogen (low maturity coals) were from 47 to $60 \mathrm{kcal} / \mathrm{mol}$, and from $10^{13}$ to $10^{16} \mathrm{~s}^{-1}$ (Ungerer et al., 1986). Elemental compositions of kerogens in Neogene Shinjo sediments plotted on a Van Krevelen diagram indicate that they are a mixture of the Type II and III kerogens (Taguchi et al., 1986). The activation energies and pre-exponential factors obtained in this study, therefore, fall within the range of reported values for bulk kerogen of Type II and III.

The bulk kinetic parameters for thermal decomposition of kerogen obtained by Rock-Eval pyrolysis are of practical use in petroleum exploration, probably because they are averaged val- ues of compound mixtures. However, it is better to know precise activation energies and preexponential factors of an individual compound not only for academic studies, but also for the petroleum exploration. Since the combined method of TG-GC/MS and TG-MS enables to estimate the activation energy and pre-exponential factor of an individual compound on the release from kerogen, this method gives detailed and useful information on the timing of petroleum generation and the quality of petroleum.

\section{Conclusions}

To determine values of kinetic parameters for individual organic compounds on the release from kerogen, five kerogen samples of different burial depth from Neogene Shinjo sediments were heated in TG from room temperature to $800^{\circ} \mathrm{C}$ at increasing rate of $5,10,20,30$, and $60^{\circ} \mathrm{C} \mathrm{min}^{-1}$, and released compounds were analyzed by GC/MS and compound release profiles by MS. The results of these analyses are summarized as follows:

1. The large peaks at about $500^{\circ} \mathrm{C}$ on the compound release profiles of $m / z 78,86,92,94,100$, and 116 by the TG-MS analysis were found and they were of benzene, hexane, toluene, phenol, heptane, and indene released from kerogen, respectively.

2. $T_{\max }$ of compounds released from the kerogen samples shifted towards higher temperature with temperature increasing rate, and fell in a range between $424.6^{\circ} \mathrm{C}$ (heptane at $5^{\circ} \mathrm{C} \mathrm{min}^{-1}$ ) and $516.9^{\circ} \mathrm{C}$ (indene at $60^{\circ} \mathrm{C} \mathrm{min}^{-1}$ ).

3. The plot of $1 / T_{\max }$ vs. $\ln \left(H \mathrm{r} /\left(T_{\max }\right)^{2}\right)$ for each compound on release showed a reasonably straight line with a high correlation coefficiency.

4. As a result of determination of the kinetic parameters of an individual compound on release from kerogens by the equation of Braun and Burnham (1987), it was found that the activation energies and pre-exponential factors fell in a range between $43.1 \mathrm{kcal} / \mathrm{mol}$ (indene) and $60.9 \mathrm{kcal} / \mathrm{mol}$ (phenol), and between $3.56 \times 10^{10} \mathrm{~s}^{-1}$ (indene) and $1.21 \times 10^{16} \mathrm{~s}^{-1}$ (phenol), respectively. 
5. The average values of these kinetic parameters had decomposition rates in order of indene $>$ benzene, toluene > phenol > hexane, heptane. Therefore, it was found that hexane and heptane were more strongly bound with kerogen matrix than benzene, toluene, and indene.

Acknowledgments-We are grateful to D. M. Jarvie, Humble Geochemical Services, who read an earlier version of this paper and provided thoughtful suggestions in addition to improved English usage. This work was supported by the Grant-in-Aid for Scientific Research (B) No. 11440166 from the Ministry of Education, Science, Sports and Culture, Japan.

\section{REFERENCES}

Braun, R. L. and Burnham, A. K. (1987) Analysis of chemical reaction kinetics using a distribution of activation energies and simpler models. Energy and Fuels 1, 153-161.

Burnham, A. K., Braun, R. L., Gregg, H. R. and Samoun, A. M. (1987) Comparison of methods for measuring kerogen pyrolysis rates and fitting kinetic parameters. Energy and Fuels 1, 452-458.

Espitalié, J., Ungerer, P., Irwin, I. and Marquis, F. (1988) Primary cracking of kerogens. Experimenting and modeling $\mathrm{C}_{1}, \mathrm{C}_{2}-\mathrm{C}_{5}, \mathrm{C}_{6}-\mathrm{C}_{15}$ and $\mathrm{C}_{15+}$ classes of hydrocarbons formed. Advances in Organic Geochemistry 1987, Org. Geochem. 13, 893-899.

Jarvie, D. M. (1991) Factors affecting Rock-Eval derived kinetic parameters. Chem. Geol. 93, 79-99.

Jarvie, D. M. and Lundell, L. L. (2001) Chapter 15: Kerogen type and thermal transformation of organic matter in the Miocene Monterey Formation. The Monterey Formation: From Rocks to Molecules (Isaacs, C. M. and Rullkotter, J., eds.), 268-295, Columbia University Press, New York.

Komiya, M., Shimoyama, A. and Harada, K. (1990) Thermal release of organic compounds from kerogen by a DTA/TG-GC/MS method. Res. Org. Geochem. 7, 59-66.

Novelli, L., Chiaramonte, M. A., Mattavelli, L., Pizzi, G., Sartori, L. and Scotti, P. (1987) Oil habitat in the Northwestern Po basin. Migration of Hydrocarbons in Sedimentary Basins (Doligez, B., ed.), 27-58, Technip, Paris.
Oba, M., Mita, H. and Shimoyama, A. (2000) Investigation of organic compounds released from kerogen in Neogene sediments of the Shinjo basin by heating experiments using a TG-GC/MS system. Res. Org. Geochem. 15, 33-42.

Shimoyama, A. and Matsubaya, O. (1985) Stable carbon isotopes of organic matter in Neogene sediments of the Shinjo basin. Geochem. J. 19, 175-179.

Sweeney, J., Talukdar, S., Burnham, A. and Vallejos, C. (1990) Pyrolysis kinetics applied to prediction of oil generation in the Maracaibo Basin, Venezuela. Org. Geochem. 16, 189-196.

Taguchi, K., Aihara, A., Akiyama, M., Ishiwatari, R., Itihara, Y., Imoto, N., Utada, M., Saito, Y., Sasaki, K., Shimada, I., Shimoda, S. and Shimoyama, A. (1983) Geology of the Oashizawa, the OhmataShiratama and the Oguni routes in the Shinjo Basin, northeastern Japan. Studies on Diagenesis of Sedimentary Rocks (Taguchi, K., ed.), 1-11, Tohoku Univ., Sendai (in Japanese).

Taguchi, K., Shimoda, S., Itihara, Y., Imoto, N., Ishiwatari, R., Shimoyama, A., Akiyama, M. and Suzuki, N. (1986) Relationship of organic and inorganic diagenesis of Neogene Tertiary rocks, Northeastern Japan. Soc. Econ. Paleon. Miner. Sp. Publ. 38, 47-64.

Tegelaar, E. W. and Noble, R. A. (1994) Kinetics of hydrocarbon generation as a function of the molecular structure of kerogen as revealed by pyrolysis-gas chromatography. Advances in Organic Geochemistry 1993, Org. Geochem. 22, 543-574.

Tissot, B. P., Pelet, R. and Ungerer, P. (1987) Thermal history of sedimentary basins, maturation indices, and kinetics of oil and gas generation. AAPG Bull. 71, 1445-1466.

Ungerer, P. and Pelet, R. (1987) Extrapolation of the kinetics of oil and gas formation from laboratory experiments to sedimentary basins. Nature 327, 52-54.

Ungerer, P., Espitalié, J., Marquis, F. and Durand, B. (1986) Use of kinetic models of organic matter evolution for the reconstruction of paleotemperatures. Application to the case of the Gironville well (France). Thermal Modeling in Sedimentary Basins (Burrus, J., ed.), 531-546, Technip, Paris.

Zumberge, J. E., Sutton, C., Martin, S. J. and Worden, R. D. (1988) Determining oil generation kinetic parameters by using a fused quartz pyrolysis system. Energy and Fuels 2, 264-266. 